\title{
Effect of the osmotic conditions during sporulation on the subsequent resistance of bacterial spores
}

\author{
Hue Nguyen Thi Minh • Stéphane Guyot • \\ Jean-Marie Perrier-Cornet • Patrick Gervais
}

Published online: 17 June 2008

(C) Springer-Verlag 2008

\section{Erratum to: Appl Microbiol Biotechnol}

DOI: 10.1007/s00253-008-1519-x

In the original version of this article the names of the authors were not complete. The name of the author Stéphane Guyot was not named. The names are shown completely here.

The online version of the original article can be found at http://dx.doi. org/10.1007/s00253-008-1519-x.

H. Nguyen Thi Minh · S. Guyot · J.-M. Perrier-Cornet $(\triangle) \cdot$

P. Gervais

Laboratoire de Génie des Procédés Microbiologiques et

Alimentaires, ENSBANA, Université de Bourgogne,

1 Esplanade Erasme,

21000 Dijon, France

e-mail: jperrier@u-bourgogne.fr 